\title{
Wpływ metali nieżelaznych na stabilność oksydacyjną paliw do silników o zapłonie samoczynnym
}

\section{Influence of non-ferrous metals on the oxidation stability of diesel fuel}

\author{
Dariusz Sacha \\ Instytut Nafty i Gazu - Państwowy Instytut Badawczy
}

\begin{abstract}
STRESZCZENIE: Wraz z szybkim wzrostem światowej gospodarki zapotrzebowanie na energię zaczęło gwałtownie rosnąć. Wzrost ten powoduje nadmierne wykorzystanie światowych zasobów paliw kopalnych. Aby poradzić sobie ze zwiększonym zapotrzebowaniem na energię, od wielu lat prowadzone są szerokie badania w dziedzinie paliw alternatywnych, a w szczególności nad biodieslem, który jest dobrym zamiennikiem oleju napędowego pochodzenia naftowego. Biodiesel ma lepsze właściwości paliwowe niż olej napędowy z ropy naftowej, ponieważ jest on odnawialny, z natury nietoksyczny i zasadniczo wolny od siarki i związków aromatycznych. Może być stosowany w dowolnym silniku wysokoprężnym bez jego modyfikacji. Jedną z wad paliw z zawartością bioestrów i biodiesli jest to, że są one podatne na utlenianie, które może wywołać polimeryzację bioestru, w wyniku czego powstaną nierozpuszczalne osady, blokujące filtry paliwowe. Kwaśne produkty reakcji utleniania bioestrów mogą powodować korozję układu napędowego. Niniejszy artykuł dotyczy oceny stabilności oksydacyjnej paliw do silników z zapłonem samoczynnym z zawartością bioestrów w kontakcie dynamicznym z metalami nieżelaznymi. Europejska norma dotycząca paliw do silników z zapłonem samoczynnym PN-EN 590+A1:2017-06 wymaga określenia stabilności oksydacyjnej w $110^{\circ} \mathrm{C}$ metodą Rancimat (PN-EN 15751), zakładając minimalny czas indukcji $20 \mathrm{~h}$. Stwierdzono negatywny wpływ metali na stabilność oksydacyjną. Ich dynamiczny kontakt z paliwem do silników o zapłonie samoczynnym zawierającym bioestry wielokrotnie przyspieszał proces utleniania, potwierdzając fakt, że metale mają katalityczny wpływ na ich stabilność oksydacyjną. Najsilniejszy negatywny wpływ na stabilność oksydacyjną miały miedź i ołów. Wykazano zależność stabilności utleniania od rodzaju metalu i czasu dynamicznego kontaktu.
\end{abstract}

Słowa kluczowe: stabilność oksydacyjna, kontakt dynamiczny, miedź, ołów, biodiesel.

ABSTRACT: With the global economy experiencing rapid growth, energy demands are rising at a very high rate, thus resulting in excessive utilisation of fossil fuel resources. To cope with the energy demand, extensive research is carried out in the field of alternative fuels. Biodiesel fuel has better fuel properties compared to petroleum diesel - it is renewable, non-toxic in nature and essentially free of sulphur and aromatics and can be used in any diesel engine without modification. One drawback of biodiesel is that it is susceptible to oxidation that can induce polymerization of the ester and can form insoluble gums and sediments that are known to cause fuel filter plugging. The present paper deals with the evaluation of the oxidation stability of biodiesel in dynamic contact with metals. The paper also investigates the impact of non-ferrous metals on the oxidation stability of various biofuel sources. The European diesel standard PN-EN 590 calls for determining oxidation stability at $110^{\circ} \mathrm{C}$ with a minimum induction time of $20 \mathrm{~h}$ with the use of the Rancimat method (PN-EN 15751). A negative effect of metals on oxidation stability was found. Metals have a catalytic effect on biodiesel stability. Even small concentrations of metal contaminants showed nearly the same impact on oxidation stability as large amounts. The strongest negative effect on oxidation stability was demonstrated by copper and lead. The dependence of oxidation stability on the type of metal and time of dynamic contact was shown.

Key words: oxidation stability, dynamic contact, copper, lead, biodiesel.

\section{Wprowadzenie}

Negatywne oddziaływanie paliw produkowanych z surowców kopalnych na środowisko stało się problemem ogólnoświatowym. Gwałtowny wzrost liczby eksploatowanych pojazdów, a co za tym idzie - gwałtowny wzrost zużycia paliw w znacznym stopniu wpływa na globalne zmiany klimatyczne. Do spełnienia wymagań norm i przepisów ochrony

Autor do korespondencji: D. Sacha, e-mail: dariusz.sacha@inig.pl

Artykuł nadesłano do Redakcji 18.03.2019 r. Zatwierdzono do druku 6.08.2019 r. 
środowiska nie wystarczają już pojedyncze środki, niezbędne są rozwiązania kompleksowe, w tym udział nowych paliw, bardziej przyjaznych dla środowiska (Jakóbiec, 2009).

W celu minimalizowania niekorzystnego oddziaływania na środowisko naturalne spalania produktów ropopochodnych, jak również zmniejszenia zużycia ropy naftowej oraz dywersyfikacji źródeł dostaw w ostatnich latach w krajach Unii Europejskiej położono duży nacisk na opracowanie technologii wytwarzania alternatywnych paliw z odnawialnych źródeł energii.

Obecnie największy udział procentowy w światowej produkcji paliw ze źródeł odnawialnych ma paliwo otrzymywane z modyfikowanych chemicznie olejów roślinnych. Unia Europejska poprzez dyrektywy nałożyła na swoich członków obowiązek zapewnienia odpowiedniego wskaźnika procentowego udziału biopaliw w ogólnym bilansie zużycia paliw.

Tabela 1. Udział biopaliw w ogólnym bilansie zużycia paliw w Polsce według Narodowego Celu Wskaźnikowego (NCW) na lata 2017-2020 (art. 7, Dz.U. z 2016 r. poz. 1986)

Table 1. The share of biofuels in the total balance of fuel consumption in Poland 2017-2020

\begin{tabular}{|c|c|}
\hline NCW & $\begin{array}{c}\text { Procentowy udzial biopaliw w ogólnym } \\
\text { bilansie zużycia paliwa [\%] }\end{array}$ \\
\hline \hline 2016 & 7,10 \\
\hline 2017 & 7,10 \\
\hline 2018 & 7,50 \\
\hline 2019 & 8,00 \\
\hline 2020 & 8,50 \\
\hline
\end{tabular}

Począwszy od 2011 r. zmieniło się podejście do redukcji $\mathrm{CO}_{2}$. W UE zaczęto większą wagę przywiązywać do źródeł pochodzenia biopaliw. Większą uwagę skupiono na biopaliwach nowej generacji produkowanych z surowców niejadalnych, np. z biomasy.

Planuje się, że w 2020 r. skończy się promocja biopaliw produkowanych z surowców jadalnych, promowane będą tylko biopaliwa otrzymywane z wydajniejszych surowców niejadalnych (Kupczyk et al., 2017).

Obowiązujące wymagania, wynikające $\mathrm{z}$ unijnych dyrektyw, są bardzo rozbudowane i dotyczą między innymi uzyskania do 2020 r. 10-procentowego udziału energii z odnawialnych źródeł w końcowym zużyciu energii w transporcie. Unia Europejska dąży również do ograniczeń związanych z maksymalnym udziałem biopaliw pierwszej generacji. Wymagania te powodują, że polskie sektory biopaliw transportowych w najbliższych latach czeka wiele zmian (Kupczyk et al., 2017).

Zmiany formulacji paliw, wynikające z nowych oczekiwań rynku, wpływają jednak w sposób niekorzystny na właściwości fizyczne i chemiczne paliw. Kilkuprocentowa zawartość
FAME (różnego pochodzenia) w oleju napędowym może powodować problemy z dotrzymaniem wielu parametrów jakościowych zawartych w wymaganiach w normie PN-EN 590+A1:2017-06. Norma ta jest europejską normą określającą właściwości fizykochemiczne, jakie powinny spełniać wszystkie sprzedawane na terenie Unii Europejskiej oleje napędowe przeznaczone do zasilania pojazdów mechanicznych wyposażonych w silniki wysokoprężne z zapłonem samoczynnym.

Kilkuprocentowa zawartość FAME w paliwie może powodować problemy przede wszystkim z dotrzymaniem wymagań odnośnie do stabilności oksydacyjnej. Ze względu na chemizm procesów utleniania FAME, całkowicie odmienny od utleniania frakcji węglowodorowych, w celu oceny stabilności oksydacyjnej paliw z zawartością FAME powyżej 2\% przewidziano do stosowania normę PN-EN 15751:2014. Normę tę wprowadzono do wymagań na olej napędowy, ustalając kryteria oceny paliw badanych zgodnie z tą procedurą (tabela 2).

Tabela 2. Wymagania normy PN-EN 590+A1:2017-06 w zakresie odporności na utlenianie

Table 2. The requirements of the standard PN-EN 590+A1:2017-06

\begin{tabular}{|c|c|c|c|c|}
\hline \multirow{2}{*}{ Wlaściwości } & \multirow{2}{*}{ Jednostka } & \multicolumn{2}{|c|}{ Zakres } & \multirow{2}{*}{$\begin{array}{c}\text { Metoda } \\
\text { badania }\end{array}$} \\
\cline { 3 - 4 } & & minimum & maksimum & \\
\hline \hline \multirow{2}{*}{$\begin{array}{c}\text { Odporność } \\
\text { na utlenianie }\end{array}$} & $\mathrm{g} / \mathrm{m}^{3}$ & & 25 & $\begin{array}{c}\text { PN-EN ISO } \\
12205\end{array}$ \\
\cline { 2 - 5 } & $\mathrm{h}$ & 20 & & $\begin{array}{c}\text { PN-EN } \\
15751\end{array}$ \\
\hline
\end{tabular}

Światowa Karta Paliw (ACEA, 2013) dopuszcza możliwość badania stabilności oksydacyjnej paliw do silników z zapłonem samoczynnym według czterech znormalizowanych metod. Oprócz metod wymienionych wyżej dopuszczona do oznaczania stabilności jest również metoda polegająca na badaniu zmiany liczby kwasowej ASTM D 664-17a, ASTM D 2274-14 (modyfikacja) oraz metoda polegająca na rejestracji spadku ciśnienia w naczyniu ciśnieniowym PN-EN 16091:2011. Metody te przedstawiono w tabeli 3.

Minimalne wartości, jakie powinno uzyskać kontrolowane paliwo, dla poszczególnych metod oznaczania stabilności przedstawiono w tabeli 4.

Parametr „,stabilność oksydacyjna paliwa” jest bardzo istotny z punktu widzenia użytkownika pojazdów mechanicznych. Ma on wpływ zarówno na eksploatację pojazdów, jak też na żywotność wielu ich podzespołów. Optymalizacja procesu spalania paliwa w silniku o zapłonie samoczynnym przy wieloetapowym wtrysku paliwa węglowodorowego lub paliwa z udziałem biokomponentów w systemie common rail wyznacza obecnie główne kierunki prac badawczych w zakresie stabilności oksydacyjnej biopaliw oraz rozwoju konstrukcji silników (Stanik et al., 2015a). 
Paliwo niespełniające wymagań w zakresie stabilności oksydacyjnej w trakcie przechowywania, zwłaszcza w okresie letnim, ulega szybkiemu procesowi utleniania. Na zdolność do utleniania FAME oraz ich mieszanin z paliwami węglowodorowymi wpływa przede wszystkim rodzaj związków wchodzących w ich skład - im więcej związków nienasyconych, tym szybciej paliwo będzie się utleniać. Szybkość utleniania nienasyconych kwasów thuszczowych lub estrów może znacznie się różnić. Sama analiza procesu utleniania jest skomplikowana, gdyż estry kwasów tłuszczowych z reguły występują w postaci złożonych mieszanin, w których w zależności od proporcji można zaobserwować procesy katalizujące lub inhibitujące samorzutne utlenianie paliwa. Sam proces utleniania następuje samorzutnie i można go przedstawić za pomocą czteroetapowego schematu reakcji rodnikowo-łańcuchowych (Gatto et al., 2006; Oleksiak i Żołty, 2012; Verma et al., 2015). Mechanizm ten zwany jest procesem samoutleniania, gdyż główne przemiany struktur związków olejowych są wynikiem przebiegających reakcji, które katalizowane są produktami kolejnych przemian.

\section{Etap I:}

Inicjacja - zapoczątkowanie łańcucha reakcji, w którym pod wpływem takich czynników jak temperatura, światło, tlen, katalityczne oddziaływanie metali powstają wolne rodniki przez rozerwanie wiązań $\mathrm{C}-\mathrm{C}$ i $\mathrm{C}-\mathrm{H}$

$$
\begin{aligned}
& \mathrm{R}-\mathrm{R} \rightarrow \mathrm{R}+\mathrm{R} \\
& \mathrm{RH} \rightarrow \mathrm{R} \cdot+\mathrm{H}
\end{aligned}
$$

\section{Etap II:}

Propagacja (rozszerzanie) łańcucha reakcji

$$
\begin{aligned}
& \mathrm{R} \cdot+\mathrm{O}_{2} \rightarrow \mathrm{ROO} \\
& \mathrm{ROO}+\mathrm{RH} \rightarrow \mathrm{ROOH}+\mathrm{R} \\
& \mathrm{HO}_{2}+\mathrm{RH} \rightarrow \mathrm{H}_{2} \mathrm{O}_{2}+\mathrm{R} \\
& \mathrm{HO}_{2} \cdot+\mathrm{RH} \rightarrow \mathrm{H}_{2} \mathrm{O}+\mathrm{RO}
\end{aligned}
$$

\section{Etap III:}

Rozgałęzienie łańcucha reakcji

$$
\begin{aligned}
& \mathrm{ROOH} \rightarrow \mathrm{RO}+\mathrm{HO} \\
& \mathrm{RO}+\mathrm{RH}+\mathrm{O}_{2} \rightarrow \mathrm{ROH}+\mathrm{ROO} \\
& \mathrm{HO}+\mathrm{RH}+\mathrm{O}_{2} \rightarrow \mathrm{H}_{2} \mathrm{O}+\mathrm{ROO}
\end{aligned}
$$
nie z $2013 \mathrm{r}$.
Tabela 3. Metody badania stabilności oksydacyjnej według Światowej Karty Paliw, wyda-

Table 3. Oxidation stability test methods according to the WCF

\begin{tabular}{|c|c|c|c|}
\hline $\begin{array}{c}\text { Stabilność } \\
\text { oksydacyjna }\end{array}$ & Nazwa & Jednostka & Metoda badawcza \\
\hline \hline Metoda 1 & Utlenianie w bloku & $\mathrm{g} / \mathrm{m}^{3}$ & $\begin{array}{c}\text { ASTM D 2274 } \\
\text { PN-EN ISO 12205 }\end{array}$ \\
\hline Metoda 2a & Rancimat modyfikacja & czas indukcji [h] & PN-EN 15751 \\
\hline Metoda 2b & Delta TAN & $\mathrm{mg} \mathrm{KOH} / \mathrm{g}$ & $\begin{array}{c}\text { ASTM D 664 } \\
\text { ASTM D 2274 (modyfikacja) }\end{array}$ \\
\hline Metoda 2c & PetroOxy & minuty & PN-EN 16091 \\
\hline
\end{tabular}

Tabela 4. Dopuszczone przez Światową Kartę Paliw (2013) minimalne wartości stabilności oksydacyjnej olejów napędowych dla poszczególnych metod

Table 4. Minimum values of oxidation stability of diesel oils according to the WCF

\begin{tabular}{|c|c|c|c|}
\hline $\begin{array}{c}\text { Stabilnośćc } \\
\text { oksydacyjna }\end{array}$ & Nazwa & Jednostka & $\begin{array}{c}\text { Minimalna wartość niezbędna } \\
\text { do spelnienia wymagań }\end{array}$ \\
\hline \hline Metoda 1 & $\begin{array}{c}\text { Utlenianie w bloku } \\
\text { ASTM D 2274 } \\
\text { PN-EN ISO 12205 }\end{array}$ & $\mathrm{g} / \mathrm{m}^{3}$ & 25 \\
\hline Metoda 2a & $\begin{array}{c}\text { Rancimat } \\
\text { PN-EN 15751 }\end{array}$ & $\mathrm{h}$ & 35 \\
\hline Metoda 2b & $\begin{array}{c}\text { Deta TAN } \\
\text { ASTM D 664 } \\
\text { ASTM 2274 (modyfikacja) }\end{array}$ & $\mathrm{mg} \mathrm{KOH/g}$ & 0,12 \\
\hline Metoda 2c & $\begin{array}{c}\text { PetroOxy } \\
\text { PN-EN 16091 }\end{array}$ & minuty & 65 \\
\hline
\end{tabular}

\section{Etap IV:}

Terminacja - zakończenie reakcji łańcuchowych

$$
\begin{aligned}
& \mathrm{R}+\mathrm{R} \cdot \rightarrow \mathrm{R}-\mathrm{R} \\
& \mathrm{R}+\mathrm{ROO} \cdot \rightarrow \mathrm{ROOR} \\
& \mathrm{ROO}+\mathrm{ROO} \rightarrow \mathrm{ROOR}+\mathrm{O}_{2}
\end{aligned}
$$

Inicjacja reakcji utleniania jest wynikiem dostarczenia energii do cząsteczki węglowodoru, m.in. w formie ciepła czy promieniowania nadfioletowego (UV). Etap inicjacji może być również katalizowany przez jony metali, które mogą znaleźć się w FAME na etapie jego produkcji z elementów konstrukcyjnych aparatury technologicznej lub zastosowanych katalizatorów metalicznych. W początkowym etapie samorzutnego utleniania stopniowo wzrasta stężenie wolnych rodników powstałych z wodoronadtlenków obecnych w tłuszczach. W temperaturze pokojowej szybkość reakcji jest mała, ale zdecydowanie wzrasta $\mathrm{w}$ podwyższonej temperaturze. Łatwość tworzenia się rodników zależna jest od siły wiązań $\mathrm{C}-\mathrm{H}, \mathrm{C}-\mathrm{C}$ i stabilności powstających rodników. W fazie propagacji, czyli autokatalitycznej rodnikowej reakcji łańcuchowej, rodniki alkilowe reagują nieodwracalnie $\mathrm{z}$ rozpuszczonym w oleju tlenem i tworzą nadtlenkowe rodniki alkilowe (peroxides). Kolejną reakcją tworzenia wodoronadtlenków i innych rodników alkilowych jest usunięcie atomu wodoru z cząsteczki 
węglowodoru. Następstwem tego jest rozgałęzienie łańcucha. Wodoronadtlenki rozszczepiają się na rodniki alkoksylowe i hydroksylowe. Rodniki reagują z węglowodorami, tworząc wodę, alkohole i coraz więcej rodników alkoksylowych. Drugo- i trzeciorzędowe rodniki alkoksylowe tworzą aldehydy, ketony i wolne kwasy karboksylowe. Produkty kondensacji mogą polimeryzować, co prowadzi do dalszej degradacji, tworząc szlamy i laki. Połączenie rodników powoduje zakończenie tych reakcji (Fitch i Gebarin, 2006).

Powstające wolne kwasy mają silne działanie korodujące, a nierozpuszczalne związki wysokocząsteczkowe (polimery, żywice) tworzą zawiesiny, szlamy i osady.

Powstałe produkty utleniania mogą uszkadzać pompy paliwowe, blokować filtry i przewody paliwowe. Osadzając się na końcówkach wtryskiwaczy, zaburzają proces wtrysku paliwa (Knothe, 2005; Hoshino et al., 2007; Jain i Sharma, 2010). Kwaśne produkty utleniania mogą przyczyniać się do degradowania elementów silnika, powodując zwiększoną korozję oraz szybsze niszczenie różnego rodzaju uszczelnień (Łukasik i Łenyk, 2008).

W celu zapewnienia odpowiedniej stabilności oksydacyjnej w trakcie przechowywania i dystrybucji do paliwa dodawane są inhibitory utleniania - antyutleniacze (Źółty i Krasodomski, 2018).

Antyutleniacze stosowane przez wiele lat do konwencjonalnych olejów napędowych nie mogły zostać wykorzystane w paliwach zawierających w swym składzie FAME lub inne produkty pochodzenia zwierzęcego czy przerobu biomasy. Obecnie stosowane antyutleniacze do paliw zostały zapożyczone z przemysłu tłuszczowego. Można je podzielić na naturalne i syntetyczne. W produkcji paliw stosowane są głównie antyutleniacze syntetyczne: BHT (butylowany hydroksytoluen), BHA (butylowany hydroksyanizol), TBHQ (tert-butylohydroksychinon), TBHT (tert-butylohydroksytoluen) (Knothe, 2007; Markowski, 2011).

Zadaniem tych dodatków jest przerwanie wolnorodnikowej reakcji utleniania. Niestety dodatki przeciwutleniające nie zatrzymują tych reakcji, a tylko je opóźniają, dlatego wszystkie paliwa mają określony czas przechowywania.

Odpowiednio dobrany dodatek antyutleniający jako komponent paliwa wprowadzony w odpowiednim stężeniu jeszcze na etapie jego produkcji pozwala uzyskać produkt, który zachowa swoje właściwości zgodne z normą PN-EN 590+A1:2017-06 w całym ciągu dystrybucyjnym, aż do momentu jego spalenia w silniku. Zakłada się, że stabilność oksydacyjna powyżej $30 \mathrm{~h}$ (test Rancimat) uzyskana na etapie produkcji jest wystarczająca, by odbiorca końcowy otrzymał produkt spełniający wymagania normy, tj. olej napędowy o stabilności powyżej 20 h.

Stabilność oksydacyjna paliwa do silników z zapłonem samoczynnym, w skład którego wchodzi FAME, zależy od wielu czynników, a wśród nich od:
- jakości produktów (głównie jakości FAME) użytych do komponowania paliwa;

- użytych dodatków antyutleniających;

- użytych innych dodatków, np. poprawiających liczbę cetanową;

- skażenia mikrobiologicznego oraz zastosowanych biocydów niwelujących jego wpływ;

- hydrolizy na skutek kontaktu z wodą lub wilgocią obecną w zbiornikach i rurociągach;

- sposobu przechowywania (temperatura, kontakt z powietrzem atmosferycznym, kontakt z wodą, światło słoneczne);

- kontaktu z metalami nieżelaznymi;

- kontaktu z uszczelnieniami elastomerowymi.

Wpływ większości wyżej wymienionych czynników jest dobrze znany i opisany w literaturze. Niekorzystne oddziaływanie różnych metali na biopaliwa jest tematem wielu badań naukowych. Badania te mają na celu określenie wpływu metali na właściwości eksploatacyjne biopaliw, a w szczególności na jego stabilność oksydacyjną. Parametr ten jest bardzo wrażliwy na obecność niektórych jonów metali w paliwie do silników o zapłonie samoczynnym.

Jak już wcześniej stwierdzono, utlenianie biopaliw jest bardzo złożonym procesem zależnym od składu chemicznego i frakcyjnego oleju napędowego oraz ilości i jakości zastosowanego FAME, temperatury, promieniowania świetlnego, sposobu magazynowania (powierzchni kontaktu paliwa z powietrzem, wielkości banki powietrza nad próbką), jak również od rodzaju zastosowanego dodatku antyutleniającego (Stanik et al., 2015b). Na proces ten dodatkowo wpływać może obecność obcych materiałów, takich jak resztkowy katalizator lub przeniesione inne składniki z surowca, które mogą przyspieszać lub hamować proces utleniania paliwa. Taki wpływ mogą mieć metale będące w kontakcie z paliwem, jak i jony matali znajdujące się w paliwie, które w sprzyjających warunkach tworzą z nim organiczne sole (Marek et al., 2015).

Na kontakt z metalami paliwo może być narażone w trakcie procesu produkcyjnego, w fazie komponowania paliwa, podczas dystrybucji paliwa za pomocą rurociągów przesyłowych czy pojazdów cysternowych oraz w trakcie przechowywania w zbiornikach magazynowych.

Szczególnie duże znaczenie ma faza produkcji biodiesla, której podstawowym procesem jest transestryfikacja katalityczna. Obecnie stosuje się wiele alternatywnych katalizatorów transestryfikacji, ale większość z nich w swoim składzie zawiera różnego rodzaju metale lub ich związki, np. tlenek wapnia czy tlenek strontu (Abramek et al., 2014). Pozostałości w biodieslu metali lub ich związków użytych jako katalizatory mogą znacząco wpływać na procesy oksydacyjne zachodzące w paliwie (Lee i Wilson 2015; Lee et al., 2017). 
Katalizatory zawierające metal można również stosować w reakcjach polimeryzacji, wytwarzając polimery z olejów roślinnych, a także wytwarzając węglowodory ze związków thuszczowych metodą hydrodezoksygenacji (Knothe et al., 2018).

Wprowadzenie przez Komisję Europejską norm zmniejszających emisję (PM - particulate matter) w gazach odlotowych silników z zapłonem samoczynnym doprowadziło do zastosowania w pojazdach mechanicznych filtrów DPF (diesel particulate filter), wymagających regeneracji np. dodatkami FBC (fuel-borne catalyst). Dodatki te w dużej mierze składają się z koloidalnych związków organicznych zawierających związki różnych metali (tlenki i wodorotlenki) zdyspergowane w dyspergacie organicznym, co również może skutkować obniżeniem odporności na utlenianie.

Ponadto obecnie zaczęto wprowadzać do paliw do silników o zapłonie samoczynnym dodatki nanocząstek tlenków metali mających wpływ na proces spalania paliwa w celu jego polepszenia i redukujących ilość emitowanych spalin (Sanders et al., 2009; Ashok et al., 2017). Wpływ tych dodatków na stabilność oksydacyjną nie został dotychczas zbadany.

Sam proces samorzutnego utleniania biodiesla pod wpływem kontaktu z jonami metali został opisany literaturze przedmiotu w sposób szczegółowy na przykładzie jonów miedzi. Ich obecność w paliwie wpływa znacząco na proces jego utleniania (Clark, 1988).

Inicjacja reakcji samorzutnego procesu utleniania następuje już w temperaturze pokojowej. Wysunięto teorię opisującą ten proces, stwierdzając, że kationy miedzi obecne w paliwie reagują z wodoronadtlenkami powstałymi w wyniku utleniania biopaliwa, tworząc reaktywne rodniki $\mathrm{ROO}^{-}$, RO-. Rodniki te odpowiedzialne są za dalszy proces utleniania paliwa (Bukrejewski i Wardzińska, 2016).

\section{Etap I:}

Inicjacja

$$
\begin{aligned}
& \mathrm{RH}+\mathrm{M}^{(\mathrm{n}+1)+} \rightarrow \mathrm{H}^{+}+\mathrm{R} \bullet+\mathrm{M}^{\mathrm{n}+} \\
& \mathrm{M}^{\mathrm{n}+}+\mathrm{O}_{2} \rightarrow \mathrm{M}^{(\mathrm{n}+1)^{+}}+\mathrm{O}_{2^{-}}^{\bullet^{-}}
\end{aligned}
$$

\section{Etap II:}

\section{Rozgałęzianie}

$$
\begin{aligned}
& \mathrm{ROOH}+\mathrm{M}^{(\mathrm{n}+1)^{+}} \rightarrow \mathrm{ROO} \bullet+\mathrm{Mn}^{+}+\mathrm{H}^{+} \\
& \mathrm{ROOH}+\mathrm{Mn}^{+} \rightarrow \mathrm{RO} \bullet+\mathrm{HO}^{-}+\mathrm{M}^{(\mathrm{n}+1)^{+}}
\end{aligned}
$$

Jak w przypadku wielu reakcji chemicznych, również w utlenianiu szybkość zwiększa się wraz ze wzrostem temperatury. Zgodnie $z$ regułą van 't Hoffa wzrost temperatury o $10 \mathrm{~K}$ powoduje zwiększenie szybkości reakcji od dwóch do czterech razy.

Jednak to, czy jony miedzi będą przyspieszały proces utleniania, czy go inhibitowały, zależy od ich stężenia w paliwie.
Obserwacje dokonane na podstawie przeprowadzonych badań pozwalają stwierdzić, że zawartość miedzi w paliwie poniżej $250 \mathrm{mg} / \mathrm{kg}$ będzie działała inhibitująco na proces jego utleniania, natomiast powyżej $250 \mathrm{mg} / \mathrm{kg}$ będzie proces ten znacząco przyspieszała.

Procesowi utleniania paliwa pod wpływem kontaktu z metalami nieżelaznymi można próbować przeciwdziałać, stosując dodatki chelatujące metale, czyli dezaktywujące negatywne oddziaływanie, zmniejszając lub całkowicie eliminując skutki ich obecności.

Podsumowując, można stwierdzić, że na zdolność do utleniania FAME lub paliw zawierających w swym składzie biokomponenty wpływa rodzaj związków wchodzących w ich skład (związki nienasycone), temperatura, promieniowanie słoneczne, dostęp do tlenu i kontakt z niektórymi metalami nieżelaznymi lub ich stopami.

W celu przeciwdziałania tym skutkom wskazane jest, by paliw nie przechowywać $\mathrm{w}$ jasnych pojemnikach, w zbiornikach narażonych na oddziaływanie promieni słonecznych i podwyższonej temperatury oraz wykonanych lub posiadających elementy wykonane z takich metali lub ich stopów, dla których zaobserwowano negatywne oddziaływanie utleniające (miedź, mosiądz, brąz, ołów, cyna czy cynk).

\section{Koncepcja badań}

Wprowadzenie do konwencjonalnych paliw pochodzenia mineralnego kilkuprocentowej zawartości bioestru, jak również wprowadzenie na rynek biopaliw o 100-procentowej zawartości bioestrów spowodowało problemy eksploatacyjne. Paliwa mimo spełnienia u producenta wymagań norm produktowych PN-EN 590+A1:2017-06 (paliwa konwencjonalne z zawartością FAME do 7\%) lub PN-EN 14214+A1:2014-04 (bioestry) w zbiornikach na stacjach paliw wymagań wyżej wymienionych norm już nie spełniały (monitoring paliw). Paliwa te w czasie procesu dystrybucji niekiedy ulegały procesowi utleniania, co powodowało pogorszenie stabilności oksydacyjnej poniżej wartości wymaganych normami przedmiotowymi.

W pracy postanowiono przeprowadzić rozszerzone badania stabilności oksydacyjnej próbek paliw do silników o zapłonie samoczynnym mających kontakt $\mathrm{z}$ różnymi metalami nieżelaznymi, które mogą powodować problemy z utrzymaniem stabilności oksydacyjnej na wymaganym poziomie.

Dotychczas prowadzone badania dotyczące wpływu matali na biopaliwa opierały się na statycznym oddziaływaniu metalu na próbkę oleju napędowego, co w uproszczony sposób obrazowało kontakt paliwa ze ściankami zbiornika lub elementami armatury dystrybucyjnej zamontowanej w zbiornikach. 
W literaturze brak jest opracowań dotyczących wpływu różnych metali na paliwo w układzie dynamicznym przedstawiającym jego przepływ przez rurociągi dystrybucyjne.

Rurociągi rozprowadzające paliwo $\mathrm{w}$ procesie produkcji oraz w trakcie przetłaczania do różnych zbiorników mimo tego, że zostały wykonane ze stali, są jednak wyposażone w różnego rodzaju armaturę sterującą, kryzy, zawory, uszczelnienia metalowe, czujniki przepływu, ciśnienia, temperatury. Większość tych elementów jest wykonana z metali nieżelaznych lub ich stopów, których oddziaływanie na paliwo nie było przedmiotem badań. Proces ten nie jest wystarczająco dobrze poznany, dlatego postanowiono zbadać ten rodzaj oddziaływania metalu na paliwo. W tym celu niezbędne było zbudowanie stanowiska badawczego obrazującego rzeczywisty dynamiczny kontakt paliwa z próbkami metalu.

Stanowisko badawcze do oceny wpływu metali na stabilność oksydacyjną paliw do silników o zapłonie samoczynnym zawierającym w swoim składzie estry metylowe kwasów thuszczowych zostało tak skonstruowane, by zapewnić dynamiczny kontakt próbki paliwa z wybranym rodzajem metalu.

Stanowisko składa się z pompy obiegowej, elementu umożliwiającego dynamiczny kontakt paliwa z próbką metalu (zbiorniczek testowy), trójnika (bajpasu), elementów sterujących służących do regulacji przepływu paliwa, zaworu zwrotnego, węży przesyłowych, pompki zasysającej.

Wszystkie elementy stanowiska w całości zostały zbudowane z materiałów niemetalicznych obojętnych dla paliwa.

Pompa obiegowa, trójnik oraz element umożliwiający dynamiczny kontakt paliwa z próbką metalu wykonane zostały z tworzywa ABS będącego kopolimerem akrylonitrylo-butadieno-styrenowym odpornym na działanie węglowodorów alifatycznych, olejów i tłuszczów (tworzywo obojętne chemicznie).

Zastosowane do budowy stanowiska węże wykonane zostały z igielitu, będącego polimerem syntetycznym z grupy polimerów winylowych otrzymywanym w wyniku polimeryzacji chlorku winylu. Węże te charakteryzują się dużą wytrzymałością mechaniczną i odpornością chemiczną.

Zawór zwrotny wykonany został z teflonu (poli(tetrafluoroetylenu), odpornego chemicznie tworzywa sztucznego.

Wyżej wymienione elementy stanowiska zamontowane zostały na przeźroczystej tablicy wykonanej z metakrylanu metylu.

Rozmieszczenie elementów testowych zostało tak dobrane, by zapewnić całkowite zalanie próbki metalu badanym paliwem bez dostępu powietrza, mogącego wpływać na wynik oznaczenia stabilności oksydacyjnej.

Czas prowadzenia testu mierzony był stoperem.

Tak skonstruowane stanowisko testowe umożliwia wykonanie badania zmiany stabilności oksydacyjnej przy dynamicznym kontakcie paliwa z próbką metalu przez określony czas. W trakcie testu po upływie założonego czasu badania można pobierać próbki paliwa w celu określenia zmiany stabilności oksydacyjnej. Pobrana odpowiednia ilość próbki paliwa pozwala oznaczyć jego stabilność oksydacyjną wg dwóch metod badawczych: PN-EN 15751:2014 oraz PN-EN 16091:2011.

Przeprowadzono rozruch stanowiska, określając możliwości regulacji przepływu i wydajności pompy obiegowej oraz dobierając określoną ilość próbki badawczej, by cały układ, a zwłaszcza zbiornik testowy, zalany był paliwem. Doświadczalnie dobrano czas badania próbek oraz określono wpływ próbki „ślepej” (próbki niemającej kontaktu z płytką metalową) na wynik oznaczenia.

Maksymalny spadek stabilności dla próby „ślepej” wyniósł $6,3 \%$. Dlatego dla uzyskania wartości poprawnej spadku stabilności oksydacyjnej w trakcie rutynowych badań postanowiono odejmować od uzyskanego wyniku wartości otrzymane dla próbki ślepej odpowiedniej do czasu oznaczenia.

Po uruchomieniu stanowiska badawczego wykonano oznaczenia wpływu dynamicznego kontaktu różnych metali na stabilność oksydacyjną paliwa do silników z zapłonem samoczynnym.

Do badań wytypowano dwa rodzaje paliwa:

1) próbkę handlowego oleju napędowego o zawartości estrów metylowych kwasów tłuszczowych do 7\% (próbka A);

2) próbkę handlowego paliwa B100 o 100\%. zawartości estrów metylowych kwasów tłuszczowych (próbka B).

Dla wyżej wymienionych paliw wykonano badanie oddziaływania różnych próbek metali i stopów stosowanych w przemyśle rafineryjnym i motoryzacyjnym.

Badania przeprowadzono na próbkach takich metali i ich stopów jak:

- miedź;

- ołów;

- aluminium;

- magnez;

- cyna;

- cynk;

- tytan;

- spoiwo (stop);

- żeliwo (stop);

- mosiądz (stop).

Dla wszystkich przedstawionych powyżej próbek metali wykonano testy ich wpływu na stabilność oksydacyjną. Wykonano oznaczenia stabilności oksydacyjnej po 5 minutach kontaktu próbki paliwa z płytką metalową, po 10 minutach, po $30 \mathrm{mi}-$ nutach, po 60 minutach i po 120 minutach.

Dla pobranych w trakcie testów próbek wykonano oznaczenia stabilności oksydacyjnej według metody badawczej PN-EN 15751:2014. 


\section{Wyniki badań}

Dla stabilności oksydacyjnej oznaczanej zgodnie ze znormalizowaną metodą PN-EN 15751 w zakresie przebadanych próbek największe spadki stabilności oksydacyjnej paliwa handlowego o zawartości FAME do 7\% odnotowano przy dynamicznym kontakcie z ołowiem. Wyjściowa stabilność próbki A, wynosząca 59,4 h, po 5-minutowym kontakcie spadła do 49 h, by po 120 minutach kontaktu osiągnąc wartość $1,8 \mathrm{~h}$, tj. spadek stabilności o 97\% (90,3\% po odjęciu próby ślepej). Podobne wartości odnotowano w przypadku miedzi. Stabilność oksydacyjna z 59,4 h dla próbki wyjściowej po 120-minutowym dynamicznym kontakcie z płytką miedzianą spadła do 34,2 h, tj. o 42,4\% (36,1\% po odjęciu próby ślepej).

Wysokie spadki stabilności oksydacyjnej zaobserwowano również dla mosiądzu, w skład którego wchodzi miedź i cynk, oraz dla spoiwa będącego stopem cyny i ołowiu.

Pozostałe przebadane metale i stopy nie wykazują znaczącego wpływu na stabilność oksydacyjną paliwa z 7-procentową zawartością FAME. Uzyskane spadki wartości stabilności oksydacyjnej kształtują się na poziomie od 3\% do 10\%. Wyniki przedstawiono $\mathrm{w}$ formie graficznej na rysunku 1.

Paliwo B100, czyli paliwo o 100-procentowej zawartości FAME, w obecności metali zachowywało się podobnie jak paliwo o 7-procentowej zawartości FAME. Największe spadki stabilności oksydacyjnej zaobserwowano w przypadku ołowiu i miedzi. Spadek stabilności dla ołowiu wynosił 47,4\% (42,1\% po odjęciu próby ślepej), a dla miedzi $71,0 \%(65,7 \%$ po odjęciu próby ślepej). Dla mosiądzu uzyskano 25-procentowy spadek stabilności oksydacyjnej, a dla spoiwa - spadek stabilności oksydacyjnej równy 14\%. Pozostałe metale nie powodowały znacznych spadków stabilności oksydacyjnej (spadki do $10 \%$ ). Wyniki przedstawiono w formie graficznej na rysunku 2.

W zakresie przebadanych próbek minimalne oddziaływanie inhibitujące $\mathrm{w}$ odniesieniu do stabilności oksydacyjnej stwierdzono dla tytanu. Zarówno dla paliwa B7 - „próbka A”, jak i dla paliwa B100 - ,próbka B” uzyskano wyniki spadku stabilności mniejsze niż w przypadku próby ślepej dla tych paliw. Wartości te nie są jednak znaczące i mogą wynikać z precyzji samej metody oznaczania stabilności oksydacyjnej.

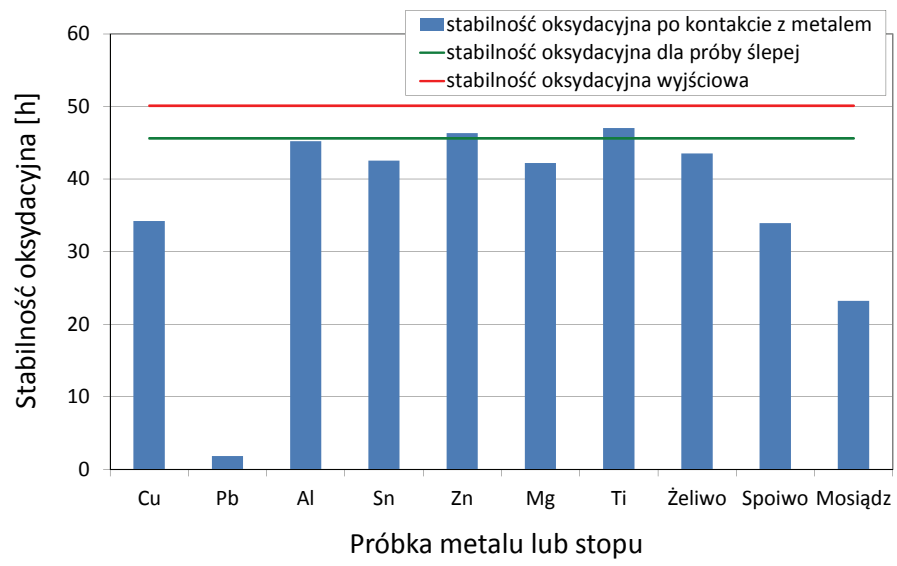

Rys. 1. Zmiana stabilności paliwa „próbka A” po 120-minutowym dynamicznym kontakcie z metalem lub jego stopem

Fig. 1. Change in fuel stability "Sample A" after 120 minutes of dynamic contact with metal or its alloy

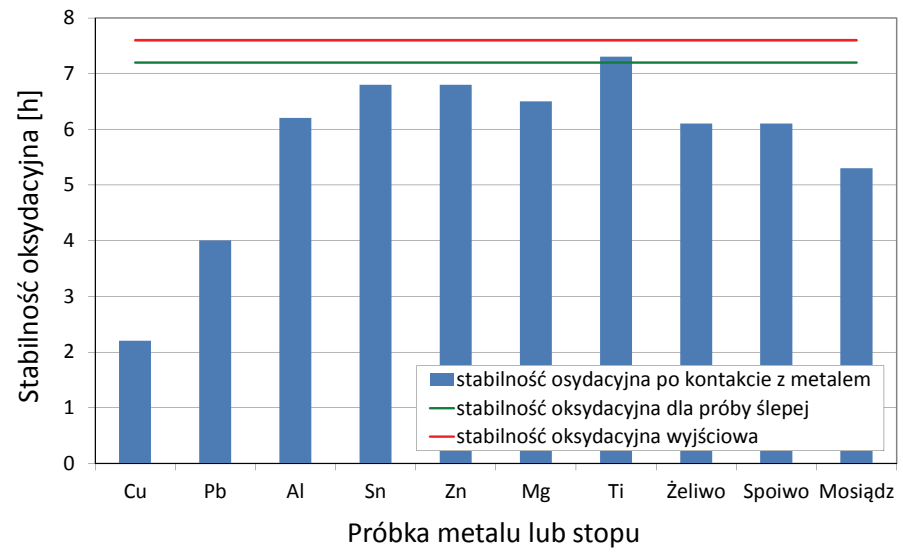

Rys. 2. Zmiana stabilności paliwa ,próbka B” po 120-minutowym dynamicznym kontakcie $\mathrm{z}$ metalem lub jego stopem

Fig. 2. Change in fuel stability "Sample B" after 120 minutes of dynamic contact with metal or its alloy

\section{Wnioski}

Porównując spadki stabilności oksydacyjnej paliwa w trakcie kontaktu dynamicznego z metalem oraz w trakcie kontaktu statycznego (tabela 5), można stwierdzić, że kontakt dynamiczny powoduje wielokrotnie większe spadki stabilności oksydacyjnej w porównaniu do kontaktu statycznego.

Tabela 5. Wyniki badań statycznych wpływu wybranych dwóch metali na stabilność oksydacyjną

Table 5. Results of static tests of the impact of the two selected metals on oxidation stability

\begin{tabular}{|c|c|c|c|c|}
\hline \multirow{2}{*}{$\begin{array}{c}\text { Czas kontaktu } \\
\text { próbki paliwa } \\
\text { z płytką metalu }\end{array}$} & $\begin{array}{c}\text { Stabilność oksydacyjna } \\
\text { wg PN-EN 15751 } \\
\text { - płytka miedziana }\end{array}$ & $\begin{array}{c}\text { Procentowy spadek } \\
\text { stabilności oksydacyjnej } \\
\text { - plytka miedziana }\end{array}$ & $\begin{array}{c}\text { Stabilność oksydacyjna } \\
\text { wg PN-EN 15751 } \\
\text { - plytka olowiana }\end{array}$ & $\begin{array}{c}\text { Procentowy spadek } \\
\text { stabilności oksydacyjnej } \\
\text { - płytka ołowiana }\end{array}$ \\
\cline { 2 - 5 } & {$[\mathbf{h}]$} & {$[\%]$} & {$[\mathbf{h}]$} & {$[\%]$} \\
\hline \hline $0 \mathrm{~min}$ & 59,0 & - & 59,0 & - \\
\hline $24 \mathrm{~h}$ & 49,1 & 16,8 & 8,1 & 86,3 \\
\hline $48 \mathrm{~h}$ & 45,1 & 23,6 & 1,3 & 97,8 \\
\hline
\end{tabular}


Określenie przyczyn zróżnicowanego oddziaływania różnych metali na stabilność oksydacyjną paliw do silników z ZS zawierających biokomponenty wymaga dalszych badań, jednak znajomość skutków tego oddziaływania może być pomocna przy doborze odpowiednich alternatywnych katalizatorów procesu transestryfikacji oraz przy doborze odpowiednich materiałów konstrukcyjnych mających kontakt, nawet chwilowy, z biopaliwami (elementy uszczelniające, sterujące, armatura pomiarowa i zabezpieczająca).

Artykuł powstał na podstawie pracy statutowej pt.: Wplyw metali nieżelaznych na stabilność oksydacyjna paliw do silników o zapłonie samoczynnym - praca INiG - PIB na zlecenie MNiSW; nr zlecenia: 0069/TE/2018, nr archiwalny: DK-4100-0069/2018.

\section{Literatura}

Abramek K., Osipowicz T., Gołębiewski W., Kowalek S., 2014. Wpływ zanieczyszczeń paliwa na zużycie wybranych elementów układu Common Rail. Autobusy: technika, eksploatacja, systemy transportowe, 5: 33-36.

ACEA - European Automobile Manufacturers' Association, 2013. Worldwide Fuel Charter, Fifth Edition. September.

Ashok B., Nanthagopal K., Mohan A., Johny A., Tamilarasu A., 2017. Comparative analysis on the effect of zinc oxide and ethanox as additives with biodiesel in CI engine. Energy, 140 (Part 1): 352-364.

Bukrejewski P., Wardzińska P., 2016. The influence of copper on the oxidation stability of commercial diesel oil. The Archives of Automotive Engineering - Archiwum Motoryzacji, 72(2): 5-14.

Clark R.H., 1988. The Role of a Metal Deactivator in Improving the Thermal Stability of Aviation Kerosines. [w:] Proceedings of the $3^{\text {rd }}$ International Conference on Stability and Handling of Liquid Fuels, London, UK, 13-16 Sept. 1988, s. 283.

Fitch J., Gebarin S., 2006. Sludge and Varnish in Turbine Systems. Practicing Oil Analysis Magazine, Noria Corporation, May.

Gatto V., Moehle W., Cobb T., Schneller E., 2006. Oxidation Fundamentals and Its Application to Turbine Oil Testing. Journal of ASTM International, 3(4): 1-20.

Hoshino T., Iwata Y., Koseki H., 2007. Oxidation stability and risk evaluation of biodiesel. Thermal Science, 11(2): 87-100.

Jain S., Sharma M., 2010. Stability of biodiesel and its blends. Renewable and Sustainable Energy Reviews, 14: 667-678.

Jakóbiec J., 2009. Procesy starzenia estrów metylowych kwasów thuszczowych oleju rzepakowego. Inżynieria Rolnicza, 5(114): 85-90.

Knothe G., 2005. Dependence of biodiesel fuel properties on the structure of fatty acid alkyl esters. Fuel Processing Technology, 86(10): 1059-1070.

Knothe G., 2007. Some aspects of biodiesel oxidative stability. Fuel Processing Technology, 88: 669-677.

Knothe G., Kevin R., Steidley K., 2018. The effect of metals and metal oxides on biodiesel oxidative stability from promotion to inhibition. Fuel Processing Technology, 177: 75-80.

Kupczyk A., Mączyńska J., Sikora M., Tucki K., Żelaziński T., 2017. Stan i perspektywy oraz uwarunkowania prawne funkcjonowania sektorów biopaliw transportowych w Polsce. Roczniki Naukowe Ekonomii Rolnictwa i Rozwoju Obszarów Wiejskich, 104(1): 39-55.

Lee A., Bennet J., Manayil J., Wilson K., 2014. Heterogeneous catalysis for sustainable biodiesel production via esterification and transesterification. Chem. Soc. Rev., 43: 7887-7916.
Lee A., Wilson K., 2015. Recent developments in heterogeneous catalysis for the sustainable production of biodiesel. Catal. Today, 242: $3-18$

Łukasik Z., Łenyk M., 2008. Działanie korozyjne paliwa biodiesel (FAME) - przyczyny i przeciwdziałanie. Archiwum Motoryzacji, 1: $51-68$.

Marek A., Hefczyc B., Stec Z., 2015. Badania szybkości inicjowania procesów wolnorodnikowych wybranymi inicjatorami. Materiaty Politechniki Sląskiej, Wydziat Chemiczny, Katedra Technologii Chemicznej, Organicznej i Petrochemii.

Markowski J., 2011. Badanie stabilności nowych dodatków FBC oraz uszlachetnionych tymi dodatkami paliw. Nafta-Gaz, 10: 736-741.

Oleksiak S., Żółty M., 2012. Wybrane metody badań do monitoringu środków smarowych. Nafta-Gaz, 58: 834-841.

Sanders J., Tock R., Yang J., 2009. Nano-sized metal and metal oxide particles for more complete fuel combustion. U.S. Patent 20090000186, p. 1.

Stanik W., Jakóbiec J., Wądrzyk M., Janus R., 2015a. Wpływ stabilności termooksydacyjnej biokomponentów ON na pracę układu wysokociśnieniowego wtrysku paliwa Common Rail. Logistyka, 5: $569-576$.

Stanik W., Mazanek A., Jakóbiec J., 2015b. Study of diesel oil containing 7\% (v/v) of FAME and cetane boost additive for the assessment its utility and purity of injectors. Combustion Engines, 162(3): 933-943.

Verma P., Sharma M., Dwivedi G., 2015. Investigation of Metals and Antioxidants on Stability Characteristics of Biodiesel. Materials Today: Proceedings, 2: 3196-3202.

Walling C., 1957. Free Radicals in Solution. John Wiley and Sons, NY: 427.

Żółty M., Krasodomski W., 2018. Stabilność oksydacyjna estrów metylowych kwasów tłuszczowych stanowiących samoistne paliwo lub biokomponent olejów napędowych. Nafta-Gaz, 5: 399-404. DOI: 10.18668/NG.2018.05.08.

\section{Akty prawne i normatywne}

PN-EN 16091:2011 Ciekłe produkty naftowe - średnie destylaty, estry metylowe kwasów tłuszczowych (FAME) i ich mieszanki - Oznaczenie stabilności oksydacyjnej w teście przyspieszonego utleniania w małej skali.

Ustawa z dnia 30 listopada 2016 r. o zmianie ustawy - Prawo energetyczne oraz niektórych innych ustaw (Dz.U. z 2016 r., poz. 1986).

PN EN 14214+A1:2014-04 Paliwa do pojazdów samochodowych - Estry metylowe kwasów tłuszczowych (FAME) do silników o zapłonie samoczynnym (Diesla) - Wymagania i metody badań.

PN-EN 15751:2014-05 Paliwa silnikowe - estry metylowe kwasów thuszczowych (FAME) jako paliwo lub komponent paliwa do silników Diesla - Oznaczanie stabilności oksydacyjnej w teście przyspieszonego utleniania.

PN-EN 590+A1:2017-06 Paliwa do pojazdów samochodowych Oleje napędowe - Wymagania i metody badań.

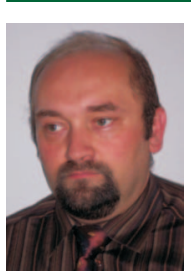

Mgr inż. Dariusz SACHA

Starszy specjalista badawczo-techniczny w Zakładzie Oceny Właściwości Eksploatacyjnych Instytut Nafty i Gazu - Państwowy Instytut Badawczy ul. Lubicz $25 \mathrm{~A}$

31-503 Kraków

E-mail: dariusz.sacha@inig.pl 